\title{
Analysis of Budget Management Performance in the Directorate of Prevention and Control of Vector and Zoonotic Disease (P2PTVZ Directorate), Ministry of Health of the Republic of Indonesia
}

\author{
Sri Cahyaningrum* \\ Administration of State Development Administrative Master Program \\ STIA LAN Jakarta Polytechnic \\ Jakarta, Indonesia \\ *Cahya.arum@gmail.comt
}

\begin{abstract}
The Ministry of Finance of the Republic of Indonesia created a web-based SMART application to facilitate work units in monitoring and evaluating budget implementation. The scores on the implementation aspect of the Directorate of Vector Infectious and Zoonotic Disease Prevention and Control (P2PTVZ Directorate) until November 2020 are as follows: Budget Performance Evaluation value: $23.86 \%$. Budget realization $19.01 \%$, realization of output volume: $57.07 \%$, achievement of activity output $10.53 \%$, consistency of initial RPD $13.68 \%$, consistency of Final RPD 95.79\%, and efficiency of 20\%. Another phenomenon is that the Supreme Audit Agency found that the Ministry of Health was ineffective in managing health funds for the 2018 fiscal year, based on BPK thematic examinations in the 2019 Semester Audit Results Summary II. The research objectives include analysing the budget execution time in the P2PTVZ Directorate with what has been planned, analysing the budget ceiling and the realization of the budget implementation at the P2PTVZ Directorate, and analysing the budget execution output at the P2PTVZ Directorate. This research methodology is qualitative. Data collection techniques using interviews, observation, and document review. The research instruments included: interview guide, observation guide, and documentation guide. The informants were 11 people with the purposive sampling technique consisting of 3 heads of sub-directorates, 3 heads of sections, 1 head of the administrative subdivision of the Directorate, 1 officer of the planning division, 1 of the procurement of goods and services, and 2 people Holders of Advances. Data analysis techniques include descriptive and interpretive, data reduction, data presentation, and drawing conclusions. Conclusion Time spent in P2PTVZ Directorate budget management - Ministry of Health of the Republic of Indonesia Mostly the same between budget management and RPD, but there are also some who postponed in the 1st quarter / beginning of the year due to certain situations. The trend in the number of budget ceilings and the realization of the total budget has decreased due to the associated budget cuts / efficiency and diverted to other program activities, also because the previous year's budget realization was low / money follow to program. Other causes are the decreasing availability of state finances,
\end{abstract}

refocusing and unplanned budget transfers at the end of the year. The trend of budget management output of the P2PTVZ Directorate - Ministry of Health of the Republic of Indonesia always exceeds the indicator target.

Keywords-performance analysis, budget management, SMART DJA

\section{BACKGROUND}

The milestones for reform in the management of state finances issued a legal umbrella, including Law Number 17 of 2003 concerning State Finances; Law Number 1 of 2004 concerning State Treasury; and Law Number 15 of 2004 concerning Audit of the Management and Accountability of State Finances. This regulation encourages the government to be more professional in terms of financial management, one of which is in the State Finance Law Article 3 paragraph 1, that State Finances are managed in an orderly manner, obeying statutory regulations, are efficient, effective, transparent, and responsible with due regard for the sense of justice and propriety. One of the things that can be used as a tool to assess the accountability of a government agency is by looking at the ministry's financial performance through calculations and analysis of target achievement and realization of revenue and expenditure on the revenue and expenditure budget, both in terms of input, output, impact and benefit. An independent performance audit is required to increase the economic value, efficiency, and effectiveness of the program which can increase public confidence in the program's tangible value and benefits.

Based on the results of the measurement, evaluation and performance accountability analysis carried out, it shows that the achievement of target indicators against strategic goals. There are still problems and obstacles faced in the implementation of activities including commitment from the SKPD leadership in achieving the performance target itself [1]. 
According to Rustini [2], There is a positive effect of compensation, work environment on organizational commitment. There is a positive effect of organizational commitment on the performance of budget managers. Broadly speaking, village financial management is in accordance with applicable regulations. Starting from the planning, budgeting, administration, reporting, accountability, until supervision stages have been implemented and more and more villages are capable and obedient to the rules for preparing the village financial system. Although the application of the principle of accountability at this stage is still limited to physical accountability, the administration side is still not fully implemented. Competence of managing human resources is a major obstacle, so that it still requires assistance from local government officials to adjust to changing rules every year [3].

Annual reports are considered a method of informing organizational stakeholders. Public sector annual reporting regulations in Australia are considered more attractive because they emphasize the purpose and presentation model of reports [4]. The annual report is a formal accountability system to inform the public about government performance in the implementation of government policies and to assist in serving and contributing to good governance [5]. Project to Improve Financial Reporting and Auditing (PIFRA) is a Pakistan initiative in reforming public sector accounting and auditing, to increase the transparency of financial reports by internal and external audits [6]. In Indonesia, based on Presidential Regulation No. 29/2014 concerning the Government Agency Performance Accountability System, it requires every government agency as an element of state government administration to be accountable for the implementation of its main duties and functions as well as resource management authority based on a strategic plan determined by each agency. Accountability is in the form of reports submitted to their respective superiors, supervisory agencies and accountability assessors, which are ultimately submitted to the President as head of government. The preparation of the Performance Accountability Report is further regulated in the Regulation of the Minister of Administrative and Bureaucratic Reform Number 53 of 2014 concerning Technical Guidelines for Performance Agreements, Performance Reporting and Procedures for Reviewing Performance Reports of Government Agencies. Based on Minister of Finance regulation 214 / PMK.02 / 2017 concerning Measurement and Evaluation of Budget Performance for Implementation of Work Plans and Budget of State Ministries / Institutions, the evaluation of budget performance on the Implementation Aspects is to produce performance information regarding the use of budgets in the context of implementing activities or programs and achieving their outputs.

The Ministry of Finance of the Republic of Indonesia created a web-based SMART application to facilitate work units in monitoring and evaluating budget implementation. Score on the implementation aspect of P2PTVZ Directorate until November 2020 as follows, the value of Budget Performance Evaluation is 23.86. Budget realization $19.01 \%$, realization of output volume $57.07 \%$, achievement of activity output $10.53 \%$, consistency of initial RPD $13.68 \%$, consistency of Final RPD $95.79 \%$, and efficiency $-20 \%$. The Supreme Audit Agency found that the Ministry of Health was less effective in managing health funds for the 2018 fiscal year, based on the BPK thematic examination in the 2019 Semester Audit Results Summary II [7].

In connection with the Supreme Audit Agency findings as well as the value of Budget Performance Evaluation and efficiency at P2PTVZ Directorate is very small, therefore it is necessary to analyse more deeply related to budget management, especially the effectiveness value in input, process, and output as well as the variables of previous research results which still have gaps.

\section{A. The problem}

- The central and regional governments sometimes encounter conflicting times because each has activities that must be carried out immediately.

- Over time, there are differences in costs between the central government and the regions or the field

- There are situations and conditions that become obstacles in achieving the planned output according to the target.

\section{B. Research purposes}

- Analyse the budget execution time at the P2PTVZ Directorate with what has been planned.

- Analysing the budget ceiling and realization of budget execution at the P2PTVZ Directorate.

- Analyse the output of budget execution at the P2PTVZ Directorate

\section{LITERATURE REVIEW}

The definition of a budget according to the Government Accounting Standards Board is a financial operating plan that includes estimates of proposed expenditures, and the sources of income that are expected to finance them within a certain period of time. According to Halim [8] the budget is a plan that is compiled in quantitative form in monetary units for one period and the budget period is usually within one year. According to Mardiasmo [9], the budget is an estimate of the performance to be achieved during a certain period of time expressed in financial terms. Conclusions that can be taken, a budget is a financial plan that is prepared and used over a certain period of time.

According to Ministry of Finance regulation 214 of 2017 concerning Measurement and Evaluation of Budget Performance for Implementation of Work Plans and Budget of State Ministries / Institutions, performance is work performance in the form of outputs from activities or programs, and results of programs with measurable quantity and quality. Budget performance is the achievement of performance on the 
use of the Ministry / Agency budget contained in budget documents. Budget performance evaluation is a process for measuring, assessing, and analysing the performance of the current budget year and the previous fiscal year to formulate recommendations in order to improve budget performance. Budget Performance Evaluation on Implementation Aspects is a Budget Performance Evaluation that is carried out to produce performance information regarding the use of the budget in the context of implementing activities or programs and achieving outputs. Activity output is the final product in the form of goods / services produced by echelon II level / work units which are implemented to achieve the activity objectives. The accountability function aims to prove and accountable in a professional manner to stakeholders for the use of managed budgets. The quality improvement function aims to measure effectiveness and efficiency, as well as identify supporting factors and constraints on the implementation of RKA-K / L in order to improve budget performance and input materials for policy formulation. Evaluation of budget performance on the implementation aspect is carried out by measuring the variables of output, budget absorption, efficiency, and consistency of budget absorption in planning. Output is measured by comparing the realization with the target activity output indicators. The absorption of the budget is measured by comparing the realization with the budget ceiling. Measurement of efficiency by comparing the difference between actual and supposed expenditures with what should be. Consistency of budget absorption in planning by taking into account the deviation between budget realization and monthly withdrawals. The weight of each variable in the implementation aspect consists of output of $43.5 \%$, efficiency of $28.6 \%$ (in general, a maximum of $20 \%$ and a minimum of $20 \%$ ), consistency of $18.2 \%$, and budget absorption of $9.7 \%$. The work unit / activity budget performance scores are grouped into categories:> 90\% very good, $80-90 \%$ good,> $60 \%-80 \%$ sufficient, $>50-60 \%$ less, $\leq 50 \%$ very poor. The definition of Value for Money based on a journal entitled Measuring the Impact and Value for Money of Governance \& Conflict Programs [10] states: "VFM is about obtaining the maximum benefit over time with the available resources. It is about achieving the right local balance between economy, efficiency and effectiveness, or, spending less, spending well and spending wisely to achieve local priorities ... VFM is high when there is an optimum balance between all three elements, when costs are relatively low, productivity is high and successful outcomes have been achieved. " The benchmark in the budget of an organization, whether for profit-oriented organizations (private) or non-profit organizations (public sector) is Value for Money, which includes an assessment of efficiency, effectiveness and economy. Where the meaning of each of these elements is:

- Efficiency is the relationship between input and output where goods and services purchased by the organization are used to achieve certain outputs. Or in other words, efficiency is the ratio of output / input associated with predetermined performance standards or targets. Efficiency is the most important thing of the three things. An organization is considered more efficient if the efficiency ratio tends to be above unity. The bigger the number, the higher the level of efficiency. Absolutely, this ratio does not indicate the company's financial position and performance. However, various programs in two companies in the same industry, the level of efficiency can be compared. If the ratio is greater than one and compared to the ratio of the same program in other companies, then the program can be said to be more efficient [11].

- Effectiveness is the relationship between output and objectives, where effectiveness is measured based on how far the level of output, policies, and procedures of the organization can achieve the stated objectives. In simple terms, effectiveness is a comparison of outcomes with outputs. Effectiveness shows success or failure in achieving goals. The measure of effectiveness is a reflection of output, so these goals must be specific, detailed, and measurable. In order to achieve goals, public sector organizations often do not pay attention to the costs incurred. This can happen when cost efficiency is not part of the outcome indicators.

- Economical is the relationship between the market and the input where goods and services are purchased at the desired quality at the best possible price. Economy is related to the extent to which public sector organizations can minimize the input resources used, namely by avoiding wasteful and unproductive spending. Economic indicators are indicators of input use.

Performance-based budgeting is a budget that connects the state budget (state expenditure) with the desired results (outputs and outcomes), so that it can be accountable for the benefit of every rupiah spent [12]. The increasing public demand for transparency in public expenditure budgeting has introduced a performance-based budgeting system (Performance Based Budgeting) as a substitute for the old budgeting system with the traditional incremental system and the line item budget structure. In the traditional system the main emphasis is on input, where the change lies in the amount of the budget that has increased compared to the previous year with less emphasis on the output to be achieved and less considering priorities and policies set nationally. Performance based budgeting is designed to create efficiency, effectiveness and accountability in the use of public spending budgets with clear outputs and outcomes in accordance with national priorities so that all budgets issued can be accounted for in a transparent manner to the wider community. The implementation of performance-based budgeting will also improve the quality of public services, and strengthen the impact of improving services to the public. To achieve all these goals, the state ministries / agencies are given greater flexibility (Let's the manager manage) to manage programs and activities supported by a higher degree of certainty over the funding for the programs and activities to be implemented. Performance Based Budgeting takes into account the relationship between 
funding and expected outputs and outcomes, including efficiency in achieving these results and outputs so that the principles of transparency, efficiency, effectiveness and accountability can be achieved. The key to understanding Performance Based Budgeting is in the word "Performance" [12]. Performance-Based Budgeting is a budgeting system that is oriented towards organizational output and is closely related to the vision, mission and strategic plan of the organization. Performance-Based Budgeting, which is allocating resources to programs not only in organizational units and using output measurement as an indicator of organizational performance [11].

To support a performance-based budgeting system that defines performance as its main objective, a clear and transparent performance measurement tool in the form of performance indicators is needed. In addition to performance indicators, clear targets are needed so that performance can be measured and compared, so that the efficiency and effectiveness of the work carried out can be assessed and the funds that have been spent to achieve the output / performance that has been set. The role of performance indicators is to provide information for consideration for decision making. The value for money indicator is divided into two parts, namely (1) cost allocation indicator (economy and efficiency), and (2) service quality indicator (effectiveness). The three points of value for money (economic, efficient, and effective) are related to one another. Economists discuss input (input), efficiency discusses input (input) and output (output), and effectiveness discusses output (output) and impact (outcome). The budget is the main tool for the government to carry out all its obligations, promises and policies into concrete and integrated plans in terms of what actions will be taken, what results will be achieved, at what costs and who will pay these costs [13]. Budgeting is divided into four stages, namely executive planning, legislative approval, executive implementation, and ex post accountability. In the first two stages, interaction between the executive and the legislature and budget politics dominates, while in (two) the last stage only involves the bureaucracy as an agent [14]

\section{A. The Theory}

The theory used is Value for Money (Figure 1).

\section{B. Principles}

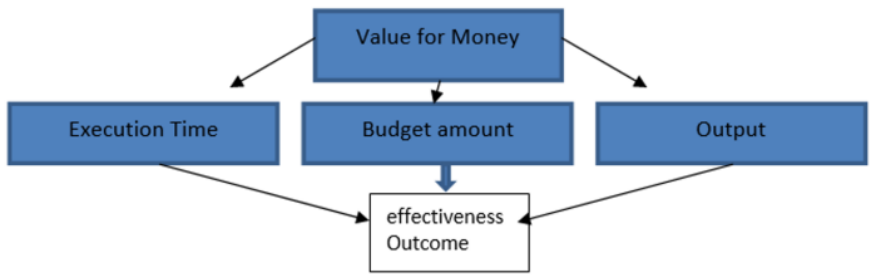

Fig. 1. Value for money.

\section{MethodOLOGY}

\section{A. Approach}

The methodological approach used is qualitative research.

\section{B. Method of Collecting Data}

Data collection methods are interviews and document review. Interview guidelines.

\section{1) Time variable}

- Consistency of Fund Withdrawal Plans (RPD) is one of the indicators for monitoring and evaluating performance. Has the RPD in budget management been properly socialized to all employees in related units?

- Is the activity implementation time used the same as the time set out in the RPD?

- What are the supporting factors for consistency of budget execution with RPD?

- What are the hindering factors / constraints related to the inconsistent budget execution with the RPD?

- What are the efforts made to overcome the inhibiting factors to the consistency of RPD?

2) Budget amount variable

- Are the costs incurred in accordance with the cost standards?

- What are the factors causing the decreased budget ceiling?

- What are the constraining factors / constraints on low budget realization?

- What are the supporting factors so that budget realization is high?

- What are the efforts made to overcome the constraining factors related to the budget amount?

3) Output variable

- How do you know that the output produced has been used as expected?

- What are the supporting factors / strategies / innovations to achieve the highest output?

- What are the factors inhibiting low output performance?

- What are the efforts made to overcome the inhibiting factors in achieving output?

- How is the explanation of budget activities that are not included in the performance indicators?

\section{Data Source}

The data sources used were informants on 11 (eleven) leaders / officials related to the budget and those who controlled budget management, namely 1) Head of Sub 
Directorate of Vector and Disease-Carrying Animals, 2) Head of Sub-Directorate for Malaria, 3) Head of Sub-Directorate for Filariasis and Worms, 4) Head of Zoonoses Section, 5) Head of Filariasis Section, 6) Head of Arboviruses section, 7) Head of Sub Division of Administration, P2PTVZ Directorate, 8) Planning Division, 9) Goods and Services Procurement Section, 10 and 11. Division of Down Payment Holders.

Review of documents in the annual report on the P2PTVZ Directorate's budget implementation for 3 years, starting from 2017 - 2019.Data analysis technique.

\section{Data Analysis Technique}

Data analysis techniques include: descriptive and interpretive, data reduction, data presentation, and drawing conclusions.

\section{CONCLUSION}

- Time spent in managing budget P2PTVZ Directorate Ministry of Health, Republic of Indonesia Mostly the same between budget management and RPD, but there are also some who postpone in the 1st quarter / beginning of the year due to certain situations. Certain situations, for example: have not entered the ecatalogue, there is no structure / Decree of the Commitment Making Officer committee / treasurer.

- The trend in the amount of the budget ceiling and the realization of the total budget has decreased due to the related cuts / efficiency of the budget and diverted to other program activities, also because the realization of the previous year's budget was low / money follow to program. Other causes are the decreasing availability of state finances, refocusing and unplanned budget transfers at the end of the year.

- The trend of budget management output of the P2PTVZ Directorate - Ministry of Health of the Republic of Indonesia always exceeds the indicator target.

\section{REFERENCES}

[1] A. Tamasoleng, "Analisis Efektivitas Pengelolaan Anggaran di Kabupaten Kepulauan Siau Tagulandang Biaro,” Jurnal Riset Bisnis dan Manajemen, vol. 3, no. 1, pp. 97-110, 2015.

[2] N.K. Rustini, "Pengaruh Kompensasi dan Lingkungan Kerja pada Komitmen Organisasi dan Implikasinya pada Kinerja Pengelola Anggaran," Jurnal Buletin Studi Ekonomi, vol. 2, no. 2, pp. 123-129, 2015.

[3] M.Z. Arifin, "Pengelolaan Anggaran Pembangunan Desa di Desa Bungin Tinggi, Kecamatan Sirah Pulau Padang, Kabupaten Ogan Komering Ilir, Sumatera Selatan," Jurnal Thengkyang, pp. 1-21, 2018.

[4] A. Chowdhury and N.C. Shil, "Exploratory Evidence on Accounting System, Annual Report Review and New Public Management," International Journal of Finance \& Managerial Accounting, vol. 4, no.16, pp. 27-37, 2020.

[5] A. Chowdhury, "Exploratory Evidence on Accounting System, Annual Report Review and New Public Management," International Journal of Finance and Managerial Accounting, pp. 27-37, 2020.

[6] W.Z. Javed Miraj, "Analysis of Public Financial Management of Pakistan," The International Journal of Business \& Management, pp. 7583, 2018.

[7] A. Alfaqir, Temuan BPK: Kemenkes Kurang Efektif Kelola Dana Kesehatan, Liputan 6, 2020. [Online] Retrieved from: https://www.liputan6.com/bisnis/read/4246372/temuan-bpk- kemenkeskurang-efektif-kelola-dana-kesehatan

[8] H. Abdul, Akuntansi Keuangan Daerah, Jakarta: Salemba Empat, 2007.

[9] Mardiasmo, Akuntansi Sektor Publik, Yogyakarta: ANDI, 2009.

[10] C. Barnett, J. Barr, A. Christie, B. Duff, and S. Hext, Measuring the Impact and Value for Money of Governance \& Conflict Programmes. Final Report, ITAD, 2010.

[11] I. Bastian, Akuntansi sektor publik. Jakarta: Erlangga, 2006.

[12] T. Kurrohman, "Evaluasi penganggaran berbasis kinerja melalui kinerja keuangan yang berbasis value for money di kabupaten/kota di Jawa Timur," Jurnal Dinamika Akuntansi, vol. 5, no. 1, 2013.

[13] P. Dobell and M. Ulrich, "Parliament's performance in the budget process: A case study," Policy Matters, vol. 3, no. 2, pp. 1-24, 2002.

[14] J. Von Hagen, "Fiscal rules, fiscal institutions, and fiscal performance," The Economic and Social review vol. 33, no. 3, pp. 263-284, 2002. 